\title{
Study of biosocial problems amongst adolescent girls of Rajapur area of Kalaburagi district of Karnataka, India
}

\author{
Amrutha Swati Indupalli ${ }^{1}$, Purushottam A. Giri ${ }^{2}$
}

\begin{abstract}
${ }^{1}$ Department of Community Medicine, Khaja Banda Nawaz Institute of Medical Sciences (KBNIMS), Kalburgi, Karnataka, India

${ }^{2}$ Department of Community Medicine, JIIU's Indian Institute of Medical Science \& Research Medical College, Badnapur, Jalna, Maharashtra, India
\end{abstract}

Received: 21 October 2015

Accepted: 12 December 2015

\section{*Correspondence:}

Dr. Amrutha Swati Indupalli,

E-mail: induswati@gmail.com

Copyright: () the author(s), publisher and licensee Medip Academy. This is an open-access article distributed under the terms of the Creative Commons Attribution Non-Commercial License, which permits unrestricted non-commercial use, distribution, and reproduction in any medium, provided the original work is properly cited.

\section{ABSTRACT}

Background: Adolescent girls are not only the future citizens but also the mother of the future nation. In this age group they have to go undergo a complex process of emotional, physical and social changes. In physical sector the menstrual problems are predominant and in psychological part the behavioral problems, negligence from the parents end, early marriage and high school drop out rate are important. The objective of the study was to study the biosocial problems amongst adolescent girls of Rajapur area of Kalaburagi district of Karnataka.

Methods: A community based cross-sectional study was carried out amongst 238 adolescent girls aged 15 -19 years in an urban community of Kalaburgi from April 2009 to March 2010. This age group is considered as it corresponds with late adolescents as per WHO.

Results: Out of 238 adolescent girls, $31.5 \%$ were married, $41.18 \%$ went to school and remaining were cases of school dropouts. $9.24 \%$ were neglected major reason for negligence of girl child was girls were not being the future earning member, in $10(4.20 \%)$ cases only among all the girls examined. $30.18 \%$ had menstrual problems most common was dysmenorrhoea (27.73\%). 36.97\% were free from behavioral problems. Depression that tops the list (63.02\%) followed by shyness $(57.14 \%)$. It was a good sign to note that addiction and suicidal tendency were at lower score $(2.1 \%$ and $1.26 \%)$ respectively.

Conclusions: In our study, we observed that root cause of behavioral morbidity was not exactly known, so we recommend that to find out the root cause, a proper psychological counselling should be done by setting up counselling centers and find out the prevalence of psychiatric problems amongst girls. With the help of these centers the increased school dropout rate can also be checked.

Keywords: Adolescent girls, Health problems, School dropout, Behavioral problems

\section{INTRODUCTION}

Adolescence word is derived from a Latin word adolescere which means "to grow up." ${ }^{1}$ It is a transitional stage of human development which includes both physical and mental development generally occurring between puberty and adulthood. In the study of adolescent development, adolescence can be defined biologically as the physical transition marked by the onset of puberty and the termination of physical growth. Cognitively it can be defined as changes in the ability to think abstractly and multi-dimensionally. Socially it can be defined as a period of preparation for adult roles. ${ }^{2}$ The major biological and pubertal changes include development of the sex organs, increase in muscle mass, increase in height and weight of the individual as well as major changes in brain structure and organization. Cognitive advances encompass both increases in 
knowledge and in the ability to think abstractly and to reason more effectively.

According to Erik Erikson's stages of human development, a young adult is generally a person between the ages of 20 and 40 years, whereas an adolescent is a person between the ages of 13 and 19 years. ${ }^{3}$ There are various programmes and policies that define the adolescents' age group differently. The ICDS programme considers adolescent girls to be between 11-18 years and the adolescents in the draft Youth Policy have been defined as the age group between 13-19 years where as the Constitution of India and labour laws of the country consider people up to the age of 14 years as children. The Reproductive and Child Health Programme mentions adolescents as being between 10-19 years of age and internationally, the age group of $10-19$ years is considered to be the age of adolescence. ${ }^{4}$ Adolescent girls are not only the future citizens but also the mother of the future nation. In this age group they have to go undergo a complex process of emotional, physical and social changes. In physical sector the menstrual problems are predominant and in psychological part the behavioral problems, negligence from the parents end, early marriage and high school drop out rate are important. Due to the natural reluctance to diagnose mental disorder in adolescents for fear of being labelled as psychiatric patients, the future of these ill-fated adolescent become gloomy. A major percentage of these girls become the victims of more serious disorders such as schizophrenia and manic-depressive disorder. Hence the present study was carried out to assess the biosocial problems amongst adolescent girls of Rajapur area of Kalaburagi district of Karnataka.

\section{METHODS}

The present study was a community based cross-sectional study, carried out amongst adolescent girls (15-19 years of age) of an urban community (Rajapur), which is a field practice area of Department of Community Medicine of M. R. Medical College, Gulbarga, Karnataka. This age group is considered as it corresponds with late adolescents as per WHO. ${ }^{5}$ The population of Rajapur was 3380. The area was selected as it was the training center, it is expected that due to the services rendered people would be more cooperative. The study was carried out from April 2009 to March 2010.

Adolescent girls constitute $10 \%$ of female population. ${ }^{6}$ We decided to include all the adolescent girls (aged 15$19 \mathrm{yrs}$ ), residing in the study area as study subjects. Detailed house to house surveys was done to know total adolescents in the area. The individuals with age group 15-19 years and willing to participate in the study were included in the study. Out of 306 people, 238 adolescents were studied after taking consent. Due care was taken to ensure that the families of the study subject were a permanent resident. In our study the interview technique and clinical examination was done maintaining full privacy. The purpose and the objective of the study were explained before to ensure cooperation. The information was collected in the pre-designed and pre-tested semistructured interview schedule. Data was collected on education, marital status, menstrual problems, etc. In the absence of the respondent during the first visit, repeat visits were paid to contact them. Data were entered in Microsoft Excel and percentage and proportion were calculated.

\section{RESULTS}

Table 1 shows the age wise distribution of adolescent girls according to marital status. It clearly shows that most of the girls $(68.49 \%)$ remain unmarried up to 19 years. Among the total 75 married girls, 30 girls belonged to 19 years of age group, contributing about $12.06 \%$ which was maximum in the married group. It also shows that maximum number of girls i.e. 66 out of 238 girls were 15 years old, contributing to $27.73 \%$.

\section{Table 1: Age and marital wise distribution of study} population.

\begin{tabular}{|lllllll|}
\hline $\begin{array}{l}\text { Age } \\
\text { (In } \\
\text { years) }\end{array}$ & \multicolumn{2}{l}{ Marital status } & \multicolumn{2}{l}{ Unmaried } & \multicolumn{2}{l|}{ Total } \\
\hline 15 & 07 & 02.94 & 59 & 24.79 & 66 & 27.73 \\
\hline 16 & 11 & 04.62 & 32 & 34.44 & 43 & 18.06 \\
\hline 17 & 09 & 03.78 & 24 & 10.01 & 33 & 13.08 \\
\hline 18 & 18 & 07.56 & 31 & 13.03 & 49 & 20.59 \\
\hline 19 & 30 & 12.06 & 17 & 07.14 & 47 & 19.74 \\
\hline Total & 75 & 31.51 & 163 & 68.49 & 238 & 100 \\
\hline
\end{tabular}

Table 2 shows the distribution of adolescent girls according to menstrual problems is shown that 165 out of 238 adolescent girls were free from menstrual problems. In the remaining 73 adolescent girls the most common menstrual problem was dysmenorrhoea $(27.73 \%)$ and oligomenorrhoea was least found in this area $(0.42 \%)$.

Table 2: Menstrual problems amongst study population.

\begin{tabular}{|lll|}
\hline Menstrual problems & $\begin{array}{l}\text { No. of } \\
\text { respondents }\end{array}$ & Percentage \\
\hline Dysmenorrhea & 66 & 27.73 \\
\hline Oligomenorrhea & 01 & 0.42 \\
\hline Menorrhagia & 04 & 1.68 \\
\hline $\begin{array}{l}\text { Combined menstrual } \\
\text { problems }\end{array}$ & 02 & 0.84 \\
\hline Normal cycles & 164 & 68.91 \\
\hline Not attained menarche & 01 & 0.42 \\
\hline Total & 232 & 100.00 \\
\hline
\end{tabular}

Table 3 shows distribution of adolescent girls according to behavioral problems. In 15-19 years age group of adolescent girls, $36.97 \%$ free from behavioral problems. 
Remaining adolescent girls suffered from depression that tops the list $(63.02 \%)$ followed by shyness $(57.14 \%)$. It was a good sign to note that addiction and suicidal tendency were at lower score i.e. $2.1 \%$ and $1.26 \%$ respectively.

Table 3: Behavioral problems amongst study population.

\begin{tabular}{|llll|}
\hline \multirow{2}{*}{$\begin{array}{l}\text { Sr. } \\
\text { no. }\end{array}$} & Behavioural Problems & \multicolumn{2}{c|}{$\begin{array}{c}\text { Adolescent girls } \\
(\mathbf{n = 2 3 8})\end{array}$} \\
\cline { 3 - 4 } & & No. & $\%$ \\
\hline 1. & Addiction & 05 & 2.10 \\
\hline 2. & Insomnia & 06 & 2.52 \\
\hline 3. & Suicidal tendency & 03 & 1.26 \\
\hline 4. & Shyness & 136 & 57.14 \\
\hline 5. & Anxiety neurosis & 13 & 5.46 \\
\hline 6. & Depression & 150 & 63.02 \\
\hline 7. & No problem & 88 & 36.97 \\
\hline$*$ *multiple response & \\
\hline
\end{tabular}

Table 4 shows distribution of neglected female children according to the reasons of neglect. In contrast to the common trend of the nation $90.76 \%$ of the $15-19$ years age group girls were not neglected here. For not being the future earning member, the girls are neglected in 10 cases only $(4.20 \%)$ among all the girls examined.

Table 4: Reasons of neglect amongst study population.

\begin{tabular}{|llll|}
\hline $\begin{array}{l}\text { Sr. } \\
\text { No. }\end{array}$ Reasons for neglecting & $\begin{array}{l}\text { No. } \\
(\mathbf{n = 2 3 8})\end{array}$ & $\%$ \\
\hline 1. & $\begin{array}{l}\text { Male as future earning } \\
\text { person }\end{array}$ & 10 & 4.20 \\
\hline 2. & Born as a girl & 06 & 2.52 \\
\hline 3. & Girl as " Paraya dhan" & 03 & 1.26 \\
\hline 4. & Dependence during old age & 03 & 1.26 \\
\hline 5. & Not neglected & 216 & 90.76 \\
\hline
\end{tabular}

Table 5: Reasons for school dropout amongst study population.

\begin{tabular}{|llll|}
\hline $\begin{array}{l}\text { Sr. } \\
\text { No. }\end{array}$ & $\begin{array}{l}\text { Reasons for school } \\
\text { dropout }\end{array}$ & $\begin{array}{l}\text { No. } \\
(\mathbf{n = 2 3 8})\end{array}$ & $\%$ \\
\hline 1. & Poor Performance & 15 & 6.30 \\
\hline 2. & Care of younger siblings & 27 & 11.34 \\
\hline 3. & Domestic work & 23 & 9.67 \\
\hline 4. & Poverty & 23 & 9.67 \\
\hline 5. & Economic Reasons & 03 & 1.26 \\
\hline 6. & Ignorance & 20 & 8.40 \\
\hline 7. & Menarche & 08 & 3.36 \\
\hline 8. & Goes to school & 98 & 41.18 \\
\hline 9. & Others & 21 & 8.82 \\
\hline
\end{tabular}

Table 5 reveals the distribution of adolescent girls according to reasons for school drop out. Among the adolescent girls of $15-19$ years of age group, $41.18 \%$ went to school and remaining were cases of school dropouts. Among the causes of school drop out, the burden to care for younger siblings tops the list with $11.34 \%$ and the other significant causes were domestic works, poverty and ignorance $9.67 \%, 9.67 \%$ and $8.40 \%$ respectively.

\section{DISCUSSION}

The duration of ages between 15 to 19 years is characterized by dramatic changes in the adolescent's physical, educational and relational contexts, as well as in biological, cognitive, emotional and social processes. ${ }^{7}$ Our study done on 238 adolescent girls, majority of the girls were unmarried up to the age of 19 years and our study had maximum girls in the age of 15 years. Our study showed that majority of the girls had regular menstruation and do not counter any menstrual disorders. In a similar study done by Begum $\mathbf{J}$ et al, revealed that $152(87.4 \%)$ respondents had regular cycles, whereas 22 $(12.7 \%)$ had irregular cycles. Difference was mainly due to environmental, racial, nutritional factors. ${ }^{8}$ In another study conducted by Patil SN where they found that $83.1 \%$ girls had regular and $16.9 \%$ had irregular cycles. ${ }^{9}$

In our study, we observed that only $36.97 \%$ was free from any behavioural problems and depression was the most common symptom the remaining girls suffered. Anne Mari Sund et al, in their study found that adolescent girls were majorly suffering from depression. ${ }^{10}$ In a study done by Mishra A and Sharma AK, found that $13.76 \%$ girls showed psychiatric morbidity. The most common problem was anxiety/depression. ${ }^{11}$ Similar findings were observed in the study done by Kashani et $\mathrm{al}^{12}$ and Cristi et al. $^{13}$

In our study, we also found a very good change in the trend that $90.76 \%$ of the adolescent group was not neglected. Arnold in his study highlighted one of the most alarming trends in India that son is given more preference. This can be a normal attribute for couples who have only girls, is accompanied by the neglect and death of millions of females through lack of medical care, improper nutrition, infanticide and sex selective abortions. $^{14}$ A study done by Das Gupta M, also observed that always son has more preference than daughters. ${ }^{15}$

A very disheartening observation of our study was that $41.18 \%$ were only school going rest of them were school drop outs due to the many reasons, one of them being the care taking of the younger siblings. Grant $\mathrm{M}$ et al, in their study observed that menstruation and its irregularity was one of the reason for school dropouts. ${ }^{16}$ Some studies argue that there are some specific characteristics of girls with dropout status include girls with poor school performance, low economic status, family migratory life styles and the consequent vulnerability of girls. Dunne Leach observed in his study that some unexpected circumstances of girls such as lack of social and economic opportunities and gender inequality in 
education system lead to motherhood and consequence dropout from schools. They also stated that the dropout rate of girls was higher than the dropout rate of boys. ${ }^{17}$

\section{CONCLUSION}

In conclusion it can be stated though the rate of early teenage marriage and the frequency of menstrual disorders are low in this area, the trend of depression in high. One fact that in this area adolescent girls were not neglected was very encouraging.

\section{Recommendations}

In our study we observed that root cause of behavioral morbidity was not exactly known, so we recommend that to find out the root cause, a proper psychological counseling should be done by setting up counseling centers and finding out the prevalence of psychiatric problems amongst girls. With the help of these centers the increased school dropout rate can also be checked.

\section{Funding: No funding sources}

Conflict of interest: None declared

Ethical approval: The study was approved by the Institutional Ethics Committee

\section{REFERENCES}

1. Macmillan Dictionary for Students Macmillan, Pan Ltd. 1981;456:14. Retrieved 2010-7-15.

2. Cote JE. Identity: A multidimensional analysis. In GR. Adams, T. Gullotta and R. Montemeyer (Eds.), New York, NY: Sage Publications Issues in Adolescent Development. 1996;6:130-80.

3. www.psychology.sunysb.edu. PSY345 Lecture Notes Ego Psychologists, ErikErikson. Retrieved 2009-08-11.

4. Bhende AA. A study of sexuality of adolescent girls and boys in underprivileged groups in Bombay. The Indian Journal of Social Work, 1994;4:557-71.

5. Adolescent and Youth Reproductive Health: 1. Introduction to Adolescent and Youth Reproductive Health

(AYRH): http://www.open.edu/openlearnworks/mod/ouconten t/view.php?id=62\&printable $=1$.

6. Kumar P, Sharama SS. Distribution of menstruation in adolescent girls. The Journal of Obstetric and Gynecology of India. 1999;49(5):42-5.
7. Michael Windle. Transitions Into Underage and Problem Drinking Summary of Developmental Processes and Mechanisms: Ages 10-15. Pediatrics 2008;121(4):S273-89.

8. Begum J, Hossain AM, Nazneen SA. Menstrual pattern and common menstrual disorders among students in Dinajpur College. Dinajpur Med Col J. 2009;2:37-43.

9. Patil SN. Health profile amongst adolescent girls in Rural area of Ratnagiri district of Maharashtra. India Journal of Clinical \& Diagnostic Research. 2009;5:1784-90.

10. Sund AM, Larsson B, Wichstrom L. Psychosocial correlates of depressive symptoms among 12-14year-old Norwegian adolescents. Journal of Child Psychology and Psychiatry. 2003;44(4):588-97.

11. Mishra A, Sharma AK. A Clinico-Social Study of Psychiatric Morbidity in 12 to 18 Years School Going Girls in Urban Delhi. Indian Journal of Community Medicine. 2001;26,(2).

12. Kashani JH, Beck NC, Hoeper EW. Psychiatric Disorders in a Community sample of Adolescents. Am J Psychiatry. 1987;144(5):584-9.

13. Christi A, Patten MA, Christian G. Depressive symptoms in California Adolescents: Family structure and parental support, Journal of Adolescent health. 1997;20:271-8.

14. Arnold, Kishor, Roy. Sex Selective Abortions in India. Population and Development Review. 2002:28(4):759-85.

15. Gupta DM. Why is Son Preference so Persistent in East and South Asia? A Cross-Country Study of China, India, and the Republic of Korea, Journal of Development Studies. 2003;40(2):153-87.

16. Grant M, Lloyd CB, Mensch B. Menstruation and school absenteeism: Evidence from rural Malawi, Comparative Education Review. 2013;57(2):260-84.

17. Gender DM. sexuality and schooling: Everyday life in junior secondary schools in Botswana and Ghana. International Journal of Educational Development. 2007;27(5):499-511.

Cite this article as: Indupalli AS, Giri PA. Study of biosocial problems amongst adolescent girls of Rajapur area of Kalaburagi district of Karnataka, India. Int J Community Med Public Health 2016;3:200-3. 